\author{
MAGDALENA STECIĄG \\ (D) https://orcid.org/0000-0002-6360-2987 \\ Uniwersytet Zielonogórski \\ Zielona Góra
}

\title{
Lingua receptiva. Wyzwania wielojęzycznej komunikacji receptywnej w Europie*
}

Lingua receptiva. Challenges of multilingual receptive communication in Europe

\begin{abstract}
The aim of the paper is to present the latest proposals within the framework of studies on receptive multilingualism. It contains a more detailed discussion of the concept of lingua receptiva, i.e. multilingual receptive communication based on (related) native languages of its participants, both in a representational aspect - in relation to actual multilingual practices, and in a configurational aspect - in relation to other categories in the conceptual grid of the research discipline. The conclusion points out that the co-occurrence of lingua receptiva and lingua franca in international communication in Europe seems to be an existing yet insufficiently recognised linguistic reality.

Keywords: receptive multilingualism, lingua receptiva, lingua franca
\end{abstract}

Sytuacja językowa na kontynencie europejskim kształtuje się obecnie w dużej mierze pod wpływem takich procesów, jak globalizacja, migracje ludności z różnych zakątków świata oraz wzmożona mobilność samych Europejczyków, które sprzyjają uczestnictwu w ponadnarodowej wspólnocie komunikacyjnej. Nie bez znaczenia w tym kontekście jest także powszechny dostęp do nowoczesnych technologii znoszących całkowicie przestrzenne bariery w komunikowaniu międzyludzkim.

Krajobraz lingwistyczny Starego Kontynentu zmienia się nie tylko ze względu na ogólne tendencje społeczno-ekonomiczne; istotnie oddziałują

* Artykuł powstał w ramach realizacji projektu badawczego „L ingua receptiva czy lingua franca? Praktyki językowe na pograniczu polsko-czeskim w obliczu dominacji angielszczyzny (ujęcie ekolingwistyczne)", finansowanego przez Narodowe Centrum Nauki (nr rej. 2017/26/E/HS2/00039). 
nań także polityczne procesy integracyjne realizowane w ramach Unii Europejskiej. Jest to szczególnie widoczne u „nowych” członków z Europy Środkowo-Wschodniej, gdzie nasila się obecność zachodniej kultury ekonomicznej, estetycznej, etycznej itd. (Mazur 2006). Znajduje to odzwierciedlenie w hierarchii języków w przestrzeni publicznej. Dodatkowo o tym, że użytkownicy dominujących w regionie języków słowiańskich są dziś ,zorientowani na Zachód", niewątpliwie może świadczyć zarówno lawinowy wzrost liczby osób uczących się języków zachodnich, a właściwie głównie angielszczyzny, jak i równie gwałtowny przyrost internacjonalnego słownictwa pochodzenia angielskiego oraz modyfikacje systemowe zachodzące pod jego wpływem w językach narodowych.

Z drugiej jednak strony polityka językowa Unii Europejskiej, respektująca językowe prawa człowieka (por. Europejską Kartę Języków Regionalnych lub Mniejszościowych) oraz promująca wielokulturowość i wielojęzyczność Europy, a także nasilające się współcześnie aspiracje separatystyczne poszczególnych państw i regionów wyznaczaja zwrot w kierunku wzmożonej troski o rodzime zasoby językowe w warunkach wszechobecności języka globalnego w zmediatyzowanym środowisku komunikacyjnym współczesnego człowieka. Warto przy tym zaznaczyć, że mimo iż skłonność do nacjonalizmu etnolingwistycznego uznaje się czasem za przypadłość Europy Środkowo-Wschodniej, nieuświadomione przyjmowanie założeń tej doktryny znajduje swój wyraz także w Europie Zachodniej - zarówno w dyskusjach głównego nurtu, jak i w nacjonalistycznych wystapieniach ugrupowań marginalnych (Blommaert, Verschueren 1998).

W obliczu tych sprzecznych tendencji, ale oddziałujących równocześnie na sytuację językową w Europie, w nurcie badań nad wielojęzycznością podejmuje się ostatnio próby przedefiniowania tradycyjnych relacji państwo (naród) - język w kierunku ich rozluźnienia oraz - przede wszystkim - pogłębioną refleksję nad możliwością uwzględnienia układów wielojęzycznych, które lepiej oddawałyby dynamikę realnych zmian. Niniejszy artykuł ma charakter przeglądu aktualnych propozycji; rozważana w nim będzie zwłaszcza koncepcja lingua receptiva, czyli receptywnej komunikacji wielojęzycznej opartej na (spokrewnionych) językach rodzimych jej uczestników, zarówno w aspekcie reprezentacyjnym - w stosunku do realnych praktyk multilingwalnych, jak i konfiguracyjnym - w stosunku do innych kategorii w siatce pojęć dyscypliny badawczej. Zostanie ona ukazana także w odniesieniu do koncepcji lingua franca - tych dwu wariantów nie należy bowiem zgodnie z zaleceniami badaczy traktować alternatywnie. Oba funkcjonuja jako ,języki wehikularne” uczestników komunikacji o zróżnicowanym zapleczu etnolingwistycznym. 


\section{Źródła \\ wielojęzycznej komunikacji receptywnej w Europie oraz jej szanse i ograniczenia}

Lingua franca to w waskim rozumieniu nazwa uproszczonego interdialektu, który powstał samoczynnie wśród kupców w portach Morza Śródziemnego w połowie średniowiecza na bazie języków: francuskiego, włoskiego, hiszpańskiego, greckiego i arabskiego. Ekonomiczne procesy internacjonalizacji pozwoliły mu przetrwać do późnych lat XIX wieku, a ewolucja samego pojęcia - dziś odnoszącego się do angielszczyzny (English as lingua franca - dalej w skrócie: ELF) - jest dobrze rozpoznana (por. np.: Brosch 2015). W średniowieczu wykształcił się jednak alternatywny model komunikacji między ludźmi władającymi różnymi językami, któremu nie poświęca się tyle uwagi. Jego kolebką był basen Morza Bałtyckiego, w którym od połowy XII wieku rozwijała się prężnie Liga Hanzeatycka. Dzięki temu, że należący do niej kupcy posługiwali się spokrewnionymi językami (z jednej strony skandynawskimi - duńskim, szwedzkim, norweskim, z drugiej - dolno- i górnosaksońskim), w kontaktach bezpośrednich efektywna okazała się wielojęzyczność receptywna (receptive multilingualism).

Zgodnie z charakterystyką Kurta Braunmüllera (2007) był to wariant używany głównie w komunikacji werbalnej w sytuacjach nieoficjalnych, w których liczy się obopólna wola porozumienia, a nacisk jest położony na skuteczność w wymianie informacji, na zrozumienie treści, bez intencji nauczenia się języka obcego. W takiej „komunikacji za wszelką cenę” na dalszy plan schodzą reguły gramatyczne i normy poprawnościowe, rośnie natomiast rola czynników pragmatycznych, sytuacyjnych i kontekstowych.

Jak zaznacza Braunmüller (2013, 217), kluczowym warunkiem skuteczności wielojęzycznej komunikacji receptywnej nie była jednak - jak mogłoby się wydawać - bliskość typologiczna używanych języków czy dialektów, lecz raczej brak ich standaryzacji i ogólnie znanych norm poprawności w odniesieniu do odmiany pisanej, co skutkowało większą elastycznością komunikacji werbalnej, wspieranej elementami para- i niewerbalnymi. Tym, co stopniowo ograniczało jej zastosowanie, były oświeceniowe ideały dotyczące języka oraz powiązanie koncepcji narodu ze wspólnotą językowa, a także do pewnego stopnia upowszechnienie pisma i druku. Z lingwistycznego punktu widzenia wielojęzyczność receptywna jest wciąż możliwa, ale tylko wówczas, gdy będzie praktykowana bez uprzedzeń - konkluduje Braunmüller. 
Pewnym ograniczeniem w upowszechnianiu wielojęzyczności receptywnej okazuje się także brak świadomości jej istnienia jako wariantu komunikacji międzyjęzykowej oraz brak doświadczenia w receptywnych praktykach multilingwalnych. Poza Skandynawia, w której funkcjonuje jako przedmiot debaty nie tylko akademickiej, ale także publicznej, nie poświęca się jej zbyt wiele uwagi. Widać to zwłaszcza w porównaniu z ożywioną dyskusją na temat roli angielszczyzny jako lingua franca (Beerkens 2010, 5). Z drugiej jednak strony traktowanie różnorodności językowej na kontynencie jako bogactwa cywilizacyjnego Europy oraz rosnący opór wobec używania ELF jako jedynego wariantu umożliwiającego porozumienie, a konkretniej - wyzwania związane z ekspansją nowych kultur i migracją ludności o bardzo zróżnicowanym zapleczu etnolingwistycznym, skłaniają do poszukiwania bardziej otwartych form komunikacji multilingwalnej.

Zainteresowanie wielojęzycznością receptywną w Europie wzrosło zwłaszcza po tym, jak Komisja Europejska przedstawiła raport, w którym uwzględnia się nowe spojrzenie na multilingwizm europejski oraz ideę różnojęzyczności, a następnie zaleca badania w obszarze komunikacji międzyjęzykowej (interlingual communication), rozpoznanie strategii komunikacyjnych i kompetencji receptywnych, które umożliwiają obopólne zrozumienie (inter-comprehension) w sytuacji, gdy uczestnicy interakcji posługują się różnymi językami, wzajemnie ich nie znając ${ }^{1}$. Doprowadziło ono do powstania i upowszechnienia koncepcji lingua receptiva (dalej w skrócie, który funkcjonuje w literaturze przedmiotu: LaRa).

\section{Lingua receptiva i pojęcia pokrewne:} od semikomunikacji do wielojęzyczności inkluzywnej

Jak zaznaczają Helka Riionheimo, Annekatrin Kaivapalu i Hanna-Ilona Härmävaara $(2017,117)$, badania nad wielojęzycznością receptywną jako odrębna dziedzina ukonstytuowały się w pierwszej dekadzie XXI w., ale wkład w ich powstanie miało liczne grono protoplastów z poprzedniego stulecia.

1 Por. European Commission. Final report high level group on multilingualism, 2007, Luxembourg: http://bookshop.europa.eu/en/high-level-group-onmultilingualism-pbNC7807451 [dostęp: 21.10.2017], zwłaszcza punkt 8 na stronie 21, a także wnioski na stronie 24. Odpowiedzią na te wytyczne jest opracowanie, w którym po raz pierwszy pojawiło się pojęcie lingua receptiva (Rehbein, ten Thije, Verschik 2011). 
W drugiej dekadzie XXI w. zakres badań rozszerzył się i obejmuje dziś kilka różnych zagadnień. Do najważniejszych należą: interkomprehencja czy wzajemna zrozumiałość (mutual intelligibility) języków spokrewnionych, podobieństwa między- lub transjęzykowe, pragmatyka interakcji receptywnych w różnych konfiguracjach językowych, obszarach i sytuacjach komunikacyjnych, stereotypy językowe i postawy użytkowników oraz polityka językowa i normatywistyka w odniesieniu do praktyki wielojęzyczności receptywnej. Wraz z poszerzeniem problematyki badawczej rozrastał się aparat pojęciowy, a rozbudowana terminologia wymaga obecnie usystematyzowania.

Początków omawianej dziedziny upatruje się w Stanach Zjednoczonych w połowie XX w., kiedy Charles F. Voegelin i Zellig S. Harris (1951) wprowadzili pojęcie stopnia zrozumiałości różnych języków spokrewnionych oraz nową metodę w badaniu interkomprehencji. Zamiast opracowywać dane antropologiczne lub pozyskiwać je droga ankietowania, pytając respondentów o zdolność rozumienia innego języka oraz jej ograniczenia, zaproponowali testowanie tych umiejętności w naturalnych lub sztucznie wytworzonych warunkach rzeczywistej komunikacji mówionej, nagrywanej do dalszej analizy za pomoca magnetofonu. Metoda ta spotkała się z krytyka antropologów, którzy wskazywali na to, że efektywność komunikacji międzyjęzykowej zależy w dużym stopniu od takich czynników, jak: nastawienie uczestników i postawy względem innych kultur, polityczna i kulturowa dominacja, a także stopień dwujęzyczności w określonym środowisku komunikacyjnym. Prekursorzy badań nad wielojęzycznością receptywną zyskali jednak w tej dyskusji ważny argument lingwistyczny o „kontinuum dialektalnym" przedstawiony przez Leonarda Bloomfielda, który wskazywał na to, że bliskie pokrewieństwo genetyczne jest nieodłącznym warunkiem zrozumiałości między dialektami (por. Bahtina-Jantsikene 2013a).

Nowa perspektywę zaprezentował wkrótce Einar Haugen na gruncie badań kontaktów międzyjęzykowych Skandynawów (Haugen 1962). Uważał on, że w systematycznych badaniach nad interkomprehencją konieczne jest uwzględnienie zarówno czynników językowych (podobieństwa typologicznego, strukturalnego, leksykalnego), jak i pozajęzykowych (nie tylko społecznych, ale także psychologicznych i kognitywnych). W tę stronę zmierzaja współcześnie szeroko zakrojone badania prowadzone w ramach projektu „Mutual intelligibility of closely related languages” (MICReLa) dla rodzin języków występujących na kontynencie europejskim. Pokazują one, że sam fakt, iż fundamenty blisko spokrewnionych języków są wspólne, a podobieństwa strukturalne - liczne, nie wyjaśnia jeszcze sukcesu lub porażki 
w receptywnym komunikowaniu się ich użytkowników. Tym, co podkreśla się od początku, jest kluczowa rola doświadczenia w praktykach wielojęzycznych oraz świadomości uczestników komunikacji, którzy muszą „nauczyć się” rozumienia języka interlokutora w toku interakcji. Jest to istotne zarówno z punktu widzenia jednostki, jak i całych społeczności, które w długoletnich kontaktach międzyjęzykowych wypracowują konwencjonalne praktyki dyskursywne oparte na wspólnej historii zdarzeń komunikacyjnych.

$\mathrm{Na}$ określenie stopnia wzajemnego zrozumienia między użytkownikami języka norweskiego, duńskiego i szwedzkiego Haugen ukuł termin semikomunikacja. Wskazywał on na niedostatki takich kontaktów, określanych metaforycznie jako „strużka przekazu w pełnym szumu kanale komunikacyjnym” (Haugen 1962, 286). Jednakże w latach 90. XX w. nastapiła zmiana w ocenie tego modelu; dostrzeżono w nim nie tyle „półśrodek” w dążeniu do porozumienia, ile budulec dyskursywnej międzykulturowości, który otwiera uczestników na trud wielojęzycznej komunikacji receptywnej. Semikomunikację zastępowano więc bardziej neutralnymi terminami, np.: receptive multilingualism, polyglot dialogue, intercomprehension i wreszcie lingua receptiva.

Obecnie na określenie sytuacji, w której uczestnicy interakcji używają różnych języków rodzimych dla osiagnięcia wzajemnego zrozumienia, używa się terminu wielojezyczność receptywna, który jest uznawany za hiperonim pozostałych wymienionych, także semikomunikacji (Marx 2011, 468). Jego zakres wykracza poza pasywna znajomość języka czy techniki nauczania języków obcych, ponieważ odnosi się do multilingwalnych strategii komunikacyjnych, na które zwykle nie zwraca się uwagi w glottodydaktyce. Jako zjawisko komunikacyjne, występujące zwłaszcza na pograniczach różnych państw o mniej lub bardziej zbliżonych językach narodowych, wielojęzyczność receptywna bywa zwykle oparta na tradycji historycznej, bliskości geograficznej oraz długoletnich stosunkach sąsiedzkich, w których toku wykształca się kompetencja receptywna - uważana za oczywistą i przez to często nieuchwytna nawet dla samych uczestników komunikacji wielojęzycznej w tym modelu. Dlatego w odniesieniu do kontekstu glottodydaktycznego bardziej właściwy jest raczej termin interkomprehencja (Blees, Thije 2016, 7).

Terminem używanym często zamiennie z wielojęzycznością receptywna jest ukute w analogii do rozpowszechnionej koncepcji lingua franca pojęcie lingua receptiva, definiowane jako ,zespół takich kompetencji językowych, mentalnych i interakcyjnych, a także międzykulturowych, które są uruchamiane podczas uczestnictwa w zdarzeniach komunikacyjnych wymagajacych biernej znajomości języka lub odmiany językowej” (Rehbein, ten Thije, Ver- 
schik 2011, 249). LaRa funkcjonuje na tym samym poziomie odniesień, co współczesna lingua franca. W obu wariantach cele komunikacyjne są podobne - osiagnięcie porozumienia w interakcji międzykulturowej, której uczestnicy wykorzystują zasoby językowe i strategie komunikacyjne umożliwiające wzajemne zrozumienie w sytuacji, gdy ich zaplecze etnolingwistyczne jest zróżnicowane. Odmienne są jednak założenia: o ile w ELF zakłada się ogólna znajomość wspólnego języka jako punkt wyjścia, za którym idą różnice w rozumieniu i stosowaniu poszczególnych form językowych, o tyle w LaRa podstawą jest zróżnicowanie zasobów językowych i idący za nim wysiłek rozpoznania w nich wspólnych form i znaczeń w celu nawiązania porozumienia (Hülmbauer 2014).

Inaczej niż interkomprehencja, która zwykle odnosi się do wzajemnego zrozumienia między użytkownikami języków blisko spokrewnionych, LaRa występuje w dwóch wariantach: „przynależnym”, gdy rozmówcy mogą porozumieć się bez konieczności podejmowania dodatkowej nauki drugiego języka i bez nadmiernego wysiłku dzięki bliskości typologicznej używanych języków, oraz „nabytym”, gdy interakcje między użytkownikami języków niespokrewnionych, którzy poprzez edukację lub ekspozycję uzyskali wiedzę „nabyta”, przebiegają efektywnie pomimo braku typologicznej bliskości, tak jak to się dzieje na przykład w przypadku mniejszościowych wspólnot etnicznych czy językowych funkcjonujących w środowisku wielojęzycznym (Bahtina, ten Thije, Wijnen 2013, 165).

Mimo wykorzystania tych wariantów w literaturze przedmiotu sami twórcy pojęcia zdają się podważać sensowność odnoszenia kryterium stopnia spokrewnienia języków do LaRa, zaznaczając, że w proponowanej przez nich perspektywie wzajemna zrozumiałość nie jest cechą poszczególnych języków, lecz wielojęzycznej komunikacji receptywnej jako procesowi negocjowania znaczeń: „LaRa będzie więc obejmować takie konfiguracje, w których nadawcy i odbiorcy dążą do zrozumienia, wymieniając się rolami i naprzemiennie używając różnych języków" (Rehbein, ten Thije, Verschik 2011, 253). W takim ujęciu siatka pojęć zbliżonych rozszerza się o termin multilingua franca, powstały odrębnie na gruncie amerykańskich badań nad multilingwizmem w wielokulturowym środowisku zglobalizowanych miast (Pennycook, Otsuji 2015).

Jeśli chodzi o zakres bardzo zbliżonych znaczeniowo pojęć wielojęzyczności receptywnej i lingua receptiva, to różnice nie są łatwe do uchwycenia. Daria Bahtina-Jantsikene zauważa, że termin receptive multilingualism jest zwykle stosowany wtedy, gdy pojęcia tego używa się bardziej „deskryptywnie”, np. 
w perspektywie historycznej czy w badaniach odnoszących się do uwarunkowań semikomunikacji w obszarach przygranicznych. Natomiast skrót LaRa jest zarezerwowany dla studiów „praktycznych”, wyjaśniających dodatkowe mechanizmy i kompetencje, których używają uczestnicy komunikacji wielojęzycznej w celu jej kontrolowania czy wspomagania przy dochodzeniu do wspólnego zrozumienia (Bahtina-Jantsikene 2013a, 21). Wydaje się, że ujawnia się tu odmienność perspektywy badawczej: o ile wielojęzyczność receptywna jest raczej rozpatrywana z perspektywy makro jako element życia społecznego, o tyle LaRa odnosi się w perspektywie mikro do jednostek podejmujących konkretne interakcje. W tym kontekście warto odróżnić wielojęzyczność (multilingwizm) jako pojęcie z zakresu socjolingwistyki odnoszące się do współistnienia określonej liczby języków w danym społeczeństwie od różnojęzyczności (plurilingwizmu) jako pojęcia z zakresu psycholingwistyki dotyczącego indywidualnych doświadczeń obcowania z różnymi językami. LaRa może być więc rozumiana jako przejaw różnojęzyczności, czyli zespołu kompetencji językowych, społecznych oraz międzykulturowych umożliwiających poszczególnym jednostkom porozumienie w zróżnicowanych konfiguracjach językowych. Ten splot kompetencji tworzy „repertuar różnojęzyczności jednostki”, który jest czymś innym niż zdolność posługiwania się kilkoma językami; to raczej zintegrowane umiejętności poruszania się w przestrzeniach międzyjęzykowych, które - niezależnie od stopnia znajomości czy zaawansowania w każdym z nich - tworzą wiedzę większą niż suma ich części (Blees, Thije 2016, 6).

Ciekawa propozycją ujmującą zróżnicowanie modeli komunikacji multilingwalnej w Europie jest wypracowana ostatnio w międzynarodowych zespole badawczym koncepcja wielojęzyczności inkluzywnej (inclusive multilingualism) promująca warianty ,niedoskonałe”, ale sprawdzające się zwłaszcza w spontanicznych kontaktach werbalnych w nieformalnym użyciu (Backus et al. 2013). Należy do nich ELF, jednakże w rozumieniu inkluzywnym odróżnia się wyraźnie od glottodydaktycznych koncepcji English as foreign language czy English of a native-like competence, które odznaczają się respektowaniem norm angielszczyzny na poziomie rodzimych użytkowników, podczas gdy ELF w podstawowym znaczeniu odnosi się do swobodniejszych użyć w sytuacji, gdy uczestnicy komunikacji nie są rodzimymi użytkownikami języka globalnego. Podobnie inkluzywnie rozumiane są regionalne lingue francae - jako zasoby językowe najbardziej użyteczne i naturalne w określonym miejscu i czasie, a także zjawiska przełączania i mieszania kodów, dopasowujące wybór języka optymalnie do potrzeb wypowiedzi lub nawet konkretnego wyrażenia. 
W centrum idei wielojęzyczności inkluzywnej tkwi jednak LaRa. Warto zauważyć, że w tradycyjnym, semikomunikacyjnym ujęciu może być ona rozpatrywana jako sposób przełączania kodów - jednakże dość radykalny, ponieważ przełączenie kodu dokonuje się w tym wariancie razem ze zmianą interlokutora. Jest to jednak sytuacja modelowa. Jak pokazują badania empiryczne, w praktyce trudno utrzymać tę dyscyplinę, a użytkownicy przełączaja języki i kody w zróżnicowany sposób: czasem automatyczny, a czasem bardziej kontrolowany, wspierając interakcję strategiami metadyskursywnymi, które służą eksplicytnemu uzasadnieniu wyborów językowych (Bahtina-Jantsikene 2013b). Sedno ukształtowania nadawczo-odbiorczego LaRa polega jednak na tym, że uczestnicy komunikacji wymieniają się rolami w toku receptywnego dyskursu wielojęzycznego, naprzemiennie mówiąc w jednym języku (rola nadawcy) i rozumiejąc w innym (rola odbiorcy). Recepcja aktów mowy w tym dyskursie ma charakter procesu o kilku stadiach rozumienia, na których odbiorca „nasiąka” językiem nadawcy (Rehbein, ten Thije, Verschik 2011, 250). Jeśli weźmie się pod uwagę nowsze i bardziej otwarte ujęcie LaRa, nieograniczające tego wariantu do blisko spokrewnionych języków rodzimych, ale z zachowaniem tradycyjnej „,natury” pragmatycznej, to okaże się, że jest ona kwintesencją wielojęzyczności inkluzywnej.

\section{Wyzwania na przyszłość}

Współcześnie LaRa wydaje się na kontynencie europejskim „językiem zagrożonym". Choć wciąż jeszcze praktykowana na pograniczach różnych państw (tam, gdzie języki są podobne, a wzajemne uprzedzenia i antagonizmy narodowe - zniwelowane), ulega dominacji ELF, która wypiera niełatwą komunikację receptywną w kontaktach międzyjęzykowych. Badania pokazuja, że nie jest to dziś opcja zakorzeniona w codziennej praktyce, ponieważ współcześnie nie chodzi o wymianę informacji „za wszelką cenę”. Zachowanie wizerunku człowieka wykształconego wymaga używania języków standardowych, a nie powoływanych ad hoc w toku interakcji tworów międzyjęzykowych (Braunmüller 2013, 218-219). Dlatego LaRa lepiej się sprawdza w sytuacjach nieoficjalnych, w komunikacji nieformalnej; w takich obszarach, jak nauka, polityka, biznes dąży się raczej do wysokiego standardu w wariancie „English only”.

Tymczasem, jak podkreślają badacze, wielojęzyczność receptywna ma wiele zalet: wspiera dążenie do zrozumienia innych kultur poprzez poszerzanie 
wspólnej płaszczyzny komunikowania, przełamuje bariery między narodami, zapewniając dobór języków na zasadzie równości i tolerancji, bez opresji czy imperializmu językowego; odpowiada też wielu oficjalnym deklaracjom w zakresie polityki językowej oraz wytycznym odnośnie do nauczania języków obcych.

Dydaktyka różnojęzyczności miewa jednak konfrontacyjny charakter. Wyrasta z przekonania, że - jak to ujmuje jedna z kuratorek projektu ,Języki bez granic” Britta Hufeisen - „różnojęzyczność jest w każdym przypadku lepsza i bardziej owocna niż jednojęzyczność lub wspólne kaleczenie języka angielskiego" (Hufeisen 2018). Z drugiej jednak strony podkreśla się, że uczestnictwo w komunikacji międzynarodowej w wariancie LaRa wspiera także otwartość na ELF, ponieważ przyczynia się do zniwelowania charakterystycznej dla osób jednojęzycznych bariery językowej czy tė̇ lęku uniemożliwiającego podjęcie jakiejkolwiek interakcji w środowisku wielokulturowym (Dewaele, Wei 2012). Tych dwu wariantów nie należy więc traktować konkurencyjnie czy alternatywnie. Ich współwystępowanie w komunikacji międzynarodowej w Europie wydaje się bowiem nie tyle prawdopodobnym scenariuszem na przyszłość, ile istniejąca - choć dotąd niewystarczająco rozpoznaną - rzeczywistością językową. Pierwsze rodzime badania diagnostyczne w tej perspektywie pokazuja, że nawet w przypadku języków blisko spokrewnionych - polskiego i czeskiego, nawet na terenach przygranicznych, na których praktyki semikomunikacyjne są silnie zakorzenione społecznie, komunikacja receptywna ulega obecnie istotnej transformacji pod presją wszechobecnej angielszczyzny: do języków narodowych, które dotąd wystarczały w codziennych kontaktach, dołącza język globalny (Steciąg 2017).

Nie bez znaczenia dla kształtu współczesnych międzyjęzykowych praktyk komunikacyjnych jest także „duch czasu”, czy też - bardziej precyzyjnie w odniesieniu do wyzwań lingwistyki XXI wieku - ,,aura intelektualna”, rozumiana jako mniej lub bardziej spójny i dynamiczny zespół przekonań ontologiczno-epistemologiczno-aksjologicznych oraz prakseologicznych, który realnie wpływa na postawy i zachowania ludzi w sposób mniej lub bardziej przez nich uświadomiony (Gajda 2013). W „płynnej rzeczywistości” postmodernizmu, charakteryzującej się wielościa punktów widzenia i zacieraniem ostrych binarnych opozycji typu: natura - kultura, obiektywizm - subiektywizm, uniwersalizm - kontekstualizm itd., zwrot zainteresowania językoznawców w kierunku pogranicznych, nietrwałych i niestandardowych form wielojęzyczności wydaje się nieuchronny. 
Bibliografia

Backus A., Gorter D., Knapp K., Schjerve-Rindler R., Swanenber J., ten Thije J.D., Vetter E., 2013, Inclusive Multilingualism: Concept, Modes and Implications, „European Journal of Applied Linguistics", nr 1.

Bahtina D., ten Thije, J.D., Wijnen, F., 2013, Combining cognitive and interactive approaches to lingua receptiva, „International Journal of Multilingualism”, nr 10/2.

Bahtina-Jantsikene D., 2013a, Mind Your Languages: Lingua Receptiva in Estonian-Russian Communication, Utrecht.

Bahtina-Jantsikene D., 2013b, Alignement in lingua receptiva: from automacity towards monitored codeswitching, „ESUKA - JEFUL”, nr 4/2.

Beerkens R., 2010, Receptive Multilingualism as a Language Mode in the Dutch-German Border Area, Münster.

Blees G., ten Thije, J.D., 2016, Receptive Multilingualism and Awareness, w: Cenoz J., Gorter D., May S., red., Language Awareness and Multilingualism, Berlin-New York.

Blommaert J., Verschueren J., 1998, The role of language in European nationalist ideologies, ,Journal of Pragmatics", nr 2.

Braunmüller K., 2007, Receptive multilingualism in Northern Europe in the Middle Ages: A description of a scenario, w: ten Thije J.D., Zeevaert L., red., Receptive multi-lingualism. Linguistic analyses, language policies and didactic concepts, Amsterdam - Philadelphia.

Braunmüller K., 2013, Communication based on receptive multilingualism: advantages and disadvantages, „International Journal of Multilingualism”, nr 10/2.

Brosch C., 2015, On the conceptual history of the term lingua franca, "Journal of Applied Language Studies", nr 9/1.

European Commission. Final report high level group on multilingualism, 2007, Luxembourg, http://bookshop.europa.eu/en/high-level-group-onmultilingualism-pbNC7807451] [dostęp: 21.10.2017].

Dewaele J.M., Wei L., 2012, Multilingualism, emphaty and multicompetence, „International Journal od Multilingualism", $\mathrm{nr} 9 / 4$.

Gajda S., 2013, Lingwistyka XXI wieku, „Polonica”, nr 33.

Gooskens C, van Heuven V.J., Golubović J., Schüppert A., Swarte F., Voigt S., 2017, Mutual intelligibility between closely related languages in Europe, „International Journal of Multilingualism”, nr 15/2.

Haugen E., 1962, Semicommunication: The language gap in Scandinavian, w: Lieberson S., red., Explorations in Sociolinguistics, Bloomington.

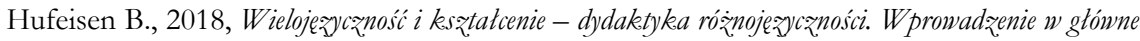
ragadnienie, http://www.goethe.de/ges/spa/prj/sog/mud/pl2984181.htm [dostęp: 21.10.2018].

Hülmbauer C., 2014, A matter of reception: ELF and LaRa compared, „Applied Linguistics Review", nr 1/5.

Marx N., 2011, Reading across the Germanic languages: Is equal access just wishful thinking?, „International Journal of Bilingualism", nr 16/4.

Mazur B., 2006, Pejzaż kulturowy krajów Europy Środkowo-Wschodniej, Białystok.

Pennycook A., Otsuji E., 2015, Metrolingualism. Language in the city, New York. 
Rehbein J., ten Thije J.D., Verschik A., 2011, Lingua Receptiva (LaRa) - remarks on the quintessence of Receptive Multilingualism, „International Journal of Bilingualism”, nr 3/16.

Riionheimo H., Kaivapalu A., Härmävaara H.I., 2017, Introduction: Receptive multilingualism, „Nordic Journal of Linguistics”, nr 40/2.

Steciag M., 2017, Lingua receptiva cay lingua franca? Pracownicy bransy ustugowo-turystycznej o komunikacji czesko-polskiej na pograniczu (badanie ankietowe), „Studia et Documenta Slavica”, nr 4.

Voegelin C.F., Harris Z.S., 1951, Methods for determining intelligibility among dialects of national languages, „Proceedings of the American Philosophical Society”, nr 95/3.

Magdalena Steciąg - dr hab., Instytut Filologii Polskiej, Uniwersytet Zielonogórski, Zielona Góra, Polska.

Językoznawczyni, której zainteresowania naukowe skupiają się wokół problemów komunikacji masowej i sposobów wykorzystywania języka w różnych dyskursach publicznych. Autorka książek: Informacja, wywiad, felieton. Sposób istnienia tradycyjnych gatunków w radiu komercyjnym (Zielona Góra 2006) i Dyskurs ekologiczny w debacie publicznej (Zielona Góra 2012), współredaktorka serii wydawniczej poświęconej komunikowaniu: Świadomość językowa w komunikowaniu (Zielona Góra 2012), Tożsamość językowa w komunikowaniu (Zielona Góra 2014), Kontakty językowe w komunikowaniu (Zielona Góra 2016) i Estetyka językowa w komunikowaniu (Zielona Góra 2019). Stypendystka na Uniwersytecie Południowej Danii w 2010 r. oraz na Uniwersytecie w Hradcu Králové w Republice Czeskiej w 2015 r.

Kontakt: M.Steciag@ifp.uz.zgora.pl 